\title{
THE EARTHQUAKE OF THE EUROPEAN ELECTION IN FRANCE. ABOUT FRONT NATIONAL, FRENCH PARTY SYSTEM AND POLITICS
}

\begin{abstract}
The victory of the National Front Party led by Ms. Marine le Pen within the European Parliamentary Election in France by May 2014 raised the question whether or not it signals the end of the French left-right bipolarized party system. This option remains uncertain. The far-right party of the 45 -year-old daughter of National Front founder, Jean-Marie Le Pen, gained new voters, deepening the national audience of the extremist party geographically and in the different categories of the population. But the still remaining French "presidentialist" constitutional political regime continues to operate under a strong constraint in favor of bipolarization. Meanwhile, the possible presence of Ms. Le Pen as the two-qualified opponent for the second round of the presidential election is currently determining, and will continue to determine for the next two years, the political strategies of the 2017 future running candidates and parties.
\end{abstract}

\section{Key words}

French Politics, European Parliamentary Election, National Front Party, Party System - New Politics

According to the Wall Street Journal in its European edition, with the "victory" of extreme right-wing National Front party led by Marine Le Pen in European Parliament Elections in May 2014, "France embraced ignominy" (Vinocur, 2014) ${ }^{1}$. The score of the FN in the polls has definitely shaken the international

* Ludovic Renard, Sciences Po Bordeaux, France, 1.renard@sciencespobordeaux.fr.

1 "On the grid of French history - from its central role in the Enlightenment, to its Nazi Collaborators in World War II (whose apologists figured among the National Front's founders), to its ambitions to make a united Europe a world-player and decision 